University of South Carolina

Scholar Commons

2014

\title{
American Shudders: Race, Representation, and Sodomy in Redburn
}

David Greven

University of South Carolina - Columbia

Follow this and additional works at: https://scholarcommons.sc.edu/engl_facpub

Part of the English Language and Literature Commons

\section{Publication Info}

Published in Leviathan, Volume 16, Issue 2, 2014, pages 1-22.

(c) Leviathan, John Hopkins University Press

Greven, D. (2014). American shudders: Race, representation, and sodomy in Redburn. Leviathan, 16(2), 1-22.

http://dx.doi.org/10.1353/Ivn.2014.0025

This Article is brought to you by the English Language and Literatures, Department of at Scholar Commons. It has been accepted for inclusion in Faculty Publications by an authorized administrator of Scholar Commons. For more information, please contact digres@mailbox.sc.edu. 


\section{PROJECT MUSE}

\section{American Shudders: Race, Representation, and Sodomy in Redburn}

Leviathan, Volume 16, Number 2, June 2014, pp. 1-22 (Article)

Published by Johns Hopkins University Press DOI: 10.1353/lvn.2014.0025

$\Rightarrow$ For additional information about this article http://muse.jhu.edu/journals/lvn/summary/v016/16.2.greven.html 


\title{
American Shudders: \\ Race, Representation, and Sodomy in Redburn
}

\author{
DAVID GREVEN \\ University of South Carolina
}

\begin{abstract}
Newer critical treatments of Redburn argue that its significance lies in its critique of antebellum slavery, most saliently in chapter 31, in which Wellingborough Redburn, the first-person narrator, offers an ekphrastic depiction of the Nelson Monument in Liverpool, England. This monument contains an especially significant detail: the four naked, chained male figures at the base of the pedestal. Redburn tells us that he can never look at their "swarthy limbs and manacles, without being involuntarily reminded of four African slaves in the market-place." The abjection of the figures is significant for understanding not only issues of race and slavery but also the queer aspects of Redburn: the vulnerability of younger males in the grip of more powerful, older males. This essay examines the connections between Melville's striking thematization of race and his representation of gender and same-sex sexuality. Race discourse here functions as a coded means of expressing and negotiating the difficulties of same-sex desire, informed by Melville's awareness of the sodomitical shipboard practices that he, throughout his work, suggested with alternate slyness and horror.
\end{abstract}

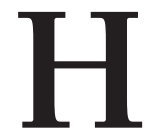

erman Melville's 1849 novel Redburn has been comparatively overlooked, with the author's own dismissive comments about the novel as hackwork done for money helping to obscure its significance. Sterling Stuckey has recently argued in his study of the influence of African art on Melville that Redburn is one of the author's most important works. I argue as well that the novel is highly significant in the Melville canon and demands fresh attention as a critique of the construction of gender and sexuality in post-Jacksonian America.

For Stuckey, Redburn's significance lies in its critique of antebellum slavery. Stuckey makes central to his argument the extraordinary set-piece in chapter 31 in which Wellingborough Redburn, the first-person narrator, exploring Liverpool, England, beholds the Nelson monument. This monument to Admiral Horatio Nelson, designed by Matthew Cotes Wyatt and sculpted by Richard Westmacott, was first publically exhibited in 1813 (see Fig. 1). Of chief interest

Vol. 16.2 (2014): 1-22 @ 2014 The Melville Society and Johns Hopkins University Press 
to Stuckey are the four naked, chained, male figures at the base of the pedestal, which the narrator describes as "seated in various attitudes of humiliation and despair . . . woe-begone figures of captives . . . emblematic of Nelson's principal victories" (NN Redburn 155). Positioned around the monument's base, these four figures are supposed to be prisoners of war who represent Nelson's victories at Cape St. Vincent (the southwestern corner of Portugal), the Nile, Copenhagen, and Trafalgar (off the southwest coast of Spain, and the site of the major British sea victory over Napoleon). Redburn tells us that he can never look at their "swarthy limbs and manacles, without being involuntarily reminded of four African slaves in the market-place" (155; see Fig. 2).

While Melville's critique of antebellum slavery in this ekphrastic episode is salient, the scene operates on allegorical levels beyond the explicit signification of race. The narrator's ability to read the sculpture in racial terms indicates, as I will show, both his own experiences of gender persecution and the threat of same-sex desire in the novel. While the abject condition of the male bodies in the sculpture evokes the suffering of enslaved Africans, the condition of abjection that the sculpture foregrounds is suggestive on other levels as well. The abjection of the figures also suggests that they are vulnerable, prey to mightier forces. This thematic informs the queer aspects of Redburn: the vulnerability of younger males in the grips of more powerful, older males is the chief theme of the novel. These valences make the allegorical figure of Death in the Nelson monument especially significant for a queer interpretation of Redburn. Death is shown sneaking up on the figure of Nelson even as he stands triumphantly above the four manacled prisoners. The figure of Death allegorizes the homoerotic threat of the older shipboard sodomite that runs throughout Redburn.

In agreement with Stuckey but with a different emphasis, I argue that an illuminating connection exists between Melville's striking thematization of race and his representation of gender and same-sex sexuality. ${ }^{1}$ What specifically concerns Melville are the myriad ways in which gendered identity affects both the possibilities of sexual experience and antebellum responses to the vexed question of racial difference. Race discourse here functions as a coded means of expressing and negotiating the difficulties of same-sex desire, informed by Melville's awareness of the sodomitical shipboard practices that he, throughout his work, suggested with alternate slyness and horror. Like other Melville works, Redburn is a Russian-doll series of embedded allegories. Its depiction of the hellishness of shipboard life allegorizes the hellishness of gender conformity; in turn, the disruptive potentiality of gender nonconformity illuminates the perils and possibilities of sexual nonconformity. The novel's critique of antebellum era racism allegorizes Melville's critique of compulsory gender roles and evocation of an alternately threatening and playful same-sex desire. 


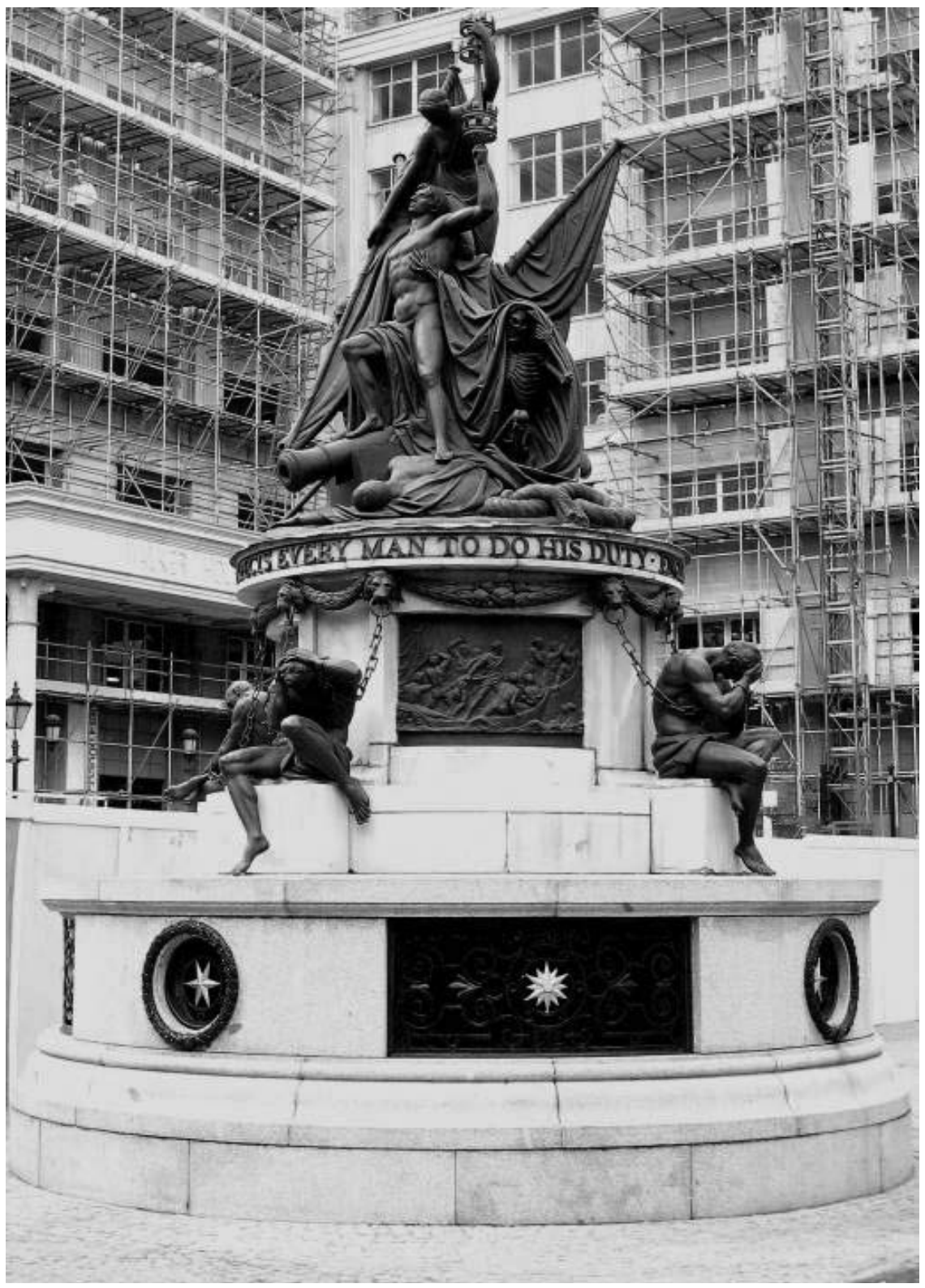

Fig. 1. The Nelson monument, by Sir Richard Westmacott (sculptor) and Matthew Cotes Wyatt (designer), unveiled Oct. 21, 1813. Located behind the Town Hall, Liverpool. Photograph by Robert Freidus, courtesy of Victorian Web. 


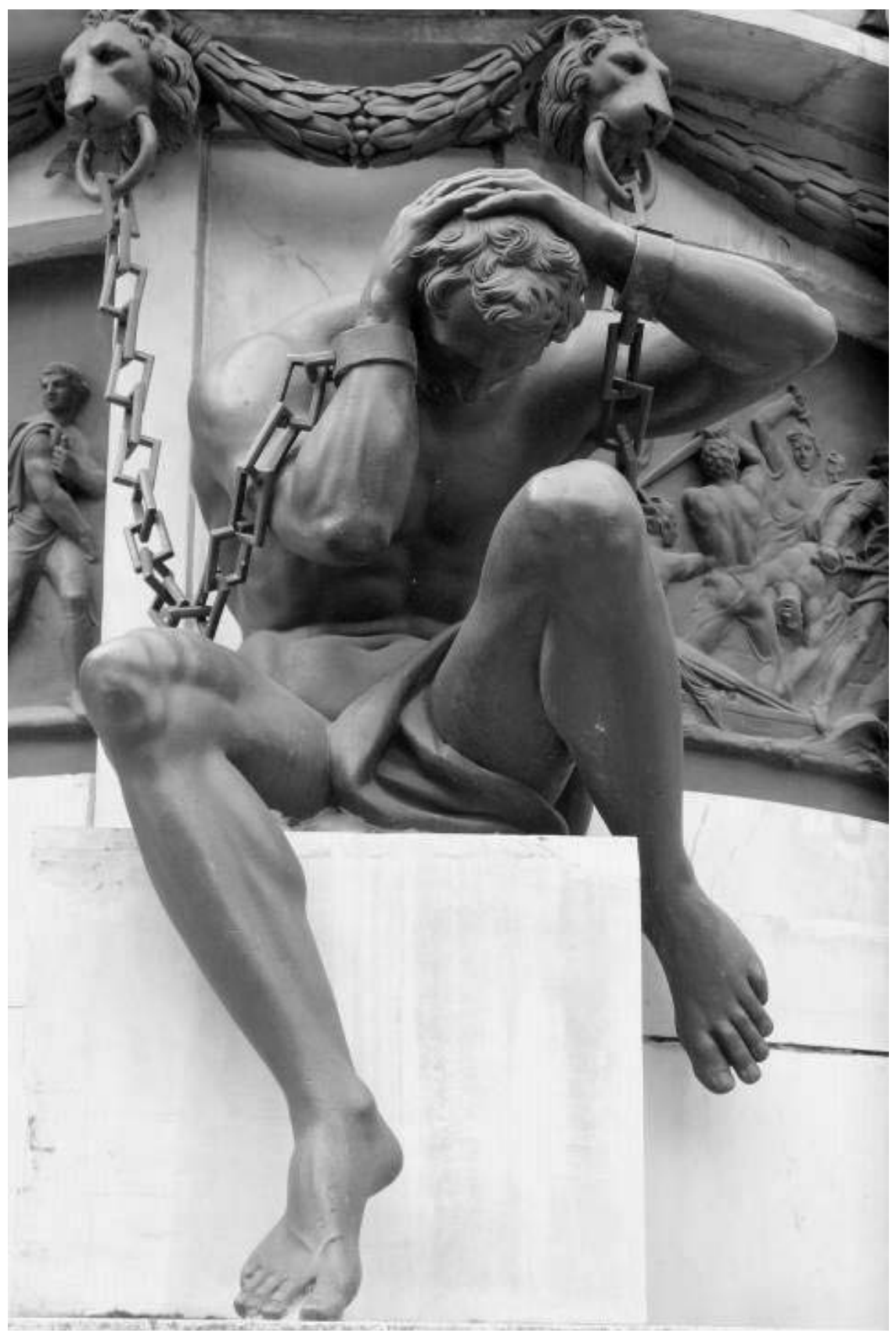

Fig. 2. One of the four naked, chained, male figures at the base of the pedestal of the Nelson monument. Photograph by Robert Freidus, courtesy of Victorian Web. 
Most of the critical discussions of the homoerotic dimensions in the novel have been restricted to considerations of the relationship between Redburn and Harry Bolton, a dapper and dissolute young Englishman who gambled away most of his inheritance and who becomes an intimate friend of the narrator, and focus on chapter 46, "A Mysterious Night in London," which describes Redburn and Harry's enigmatic adventures in "Aladdin's Palace." Robert K. Martin argued that Aladdin's Palace should be read as a depiction of a male brothel. ${ }^{2}$ James Creech similarly argues that Harry Bolton represents the historical emergence of the homosexual typing of the effeminate dandy, whose gendered deviations come to be linked to the larger transgression of samesex desire. Specifically, Creech reads Harry as a hustler in London's East End. ${ }^{3}$ While characters such as Harry Bolton and also Carlo, the handsome young "organ-playing" Italian youth who appears later in the novel, are important to its homoerotic themes, my focus here will be on the significance of Redburn's interpretation of the Nelson monument for an understanding of queer sexuality in Melville's works.

While not a critic who has made a case for a queer Melville, Hershel Parker has made it clear that the author was aware not only of the potential for shipboard sodomy but of the frequency with which it occurred, and, moreover, that Melville thematized these practices in his sea fictions (530-31, 657). Robert K. Martin focuses on Melville's awareness of and interest in same-sex desire, depicting the relations between men in largely positive terms, without discussing the considerable level of unease and the potential for violence that suffuse these relations. Caleb Crain has discussed the ways in which Melville treats the relationships between men at sea as rife with abuses of power that are suggestive of sodomitical rape. ${ }^{4}$ Cesare Casarino has analyzed Melville's view of shipboard communities as dens of vice and violation.

A historical account of these matters illuminates Melville's fictional rendering. The entries in the private journal of an antebellum Navy drummer, Philip C. Van Buskirk, strike similarly ominous notes about male-male sexual encounters and make for a telling comparison with Melville's writings. Buskirk's journal reveals the fears and attractions of same-gender sex at sea. In one year, his entries range from reporting an incident in which "An Old Reprobate" attempts to involve him in sexual activity- "I soon perceived myself to be in that condition which is attached to all boys upon first entering the service- the being the object of a $S$ - te's desires" - to outlining carefully distinctions between the terms "paederasty," a term he first encounters in "Gibbon's Rome," and "Sodomy" (italics in the original). Belying the current, oft-repeated commonplace that same-sex sleeping arrangements were routine activities that revealed little about sexual desires and never raised an antebellum eyebrow-a 
commonplace employed, for example, in rebuttal to questions over Abraham Lincoln's sexuality and relationship with his long-term friend Joshua Speedthis Buskirk entry recounts a fraught conversation:

Suspicious Conduct. Since the $17^{\text {th }}$ of this month, I have every night shared my pallet with ... Joe ... and this conduct is food for scandal. A Quartermaster, quick to criminate, attacked me the other day with- "Well! You lays alongside o'boys now o'nights, do you. ... Why, ain't you ashamed of yourself to have a boy alongside of you all night'. . . . why, that boy would_— - jackass! ... Oh, Hell! now do you mean to say that you sleeps alongside o'boys o'nights and do'nt [sic] do nothing?"

In other words, unhandsomely done, my lad. Despite his protestations of unblemished conduct to the apoplectic Quartermaster, an anguished Buskirk confesses a month later that he "was led last night by a series of evil thoughts to the perpetration of that damning crime - the bane of my soul." As if he had read the tracts of reformers such as Sylvester Graham and John Todd, Buskirk writes that "I'D THINK NATURE had cursed me at my birth."

Unknown by Melville, Buskirk's text was contemporaneous with his own major work. Melville's writings exhibit a similar dread of and attraction to same-gender sex. Between Redburn and Buskirk's diaries, a powerful repertoire of images and tropes related to same-sex desiring themes emerges. The predatory advances of an older "reprobate" toward a younger and more vulnerable man becomes a topos of nautical same-sex desire and danger in these and other antebellum writings.

Of significance as well to questions of nineteenth-century sexual history is the provocative and problematic nineteenth-century preoccupation with Hellenism, foregrounded in Melville's chapter on the Nelson monument. Hellenism, the celebration of ancient Greece as the pinnacle of human civilization, often took visible form in classical sculpture, which had become a metonymic object of aesthetic and cultural fascination. Racially and homoerotically charged, the idealization of the white figures of classical sculpture in nineteenth-century America evinces what was problematic and resistant in Hellenism: its promotion of a white racial ideal and its usefulness as a mode for the expression of homoerotic desire. The German art historian and archaeologist Johann Joachim Winckelmann (1717-1768), whose influential book The History of Art would be read by Melville and Hawthorne in the 1850s, popularized the myth of ancient Greece as the apex of human civilization and encouraged the cultivation of aesthetic sensibility tied to what would become known as the "Grand Tour," frequently undertaken by young men as they roamed about Europe seeking classical sculptures, often of youthful male figures. ${ }^{6}$ I will return to the issue of Hellenism and Winckelmann's influence below. For 
now, let me establish that Redburn is significant text for the more recent turn to questions of the aesthetic, in nineteenth-century American literature generally and specifically in Melville's work.

Christopher Looby, discussing "The Counterpane," the early chapter of Moby-Dick (1851) in which Ishmael and Queequeg spend the night together, nestled beneath the titular bedspread, closely attends to aesthetics as a sensual, rather than a sexual, mode of same-sex connection. "When Ishmael does come to be able to tell the difference between Queequeg's arm and the counterpane it rests upon-when, we might say, aesthetics and erotics split apart in this Melvillean micro-drama of closely observed sensory experience-we then have," argues Looby, "an emblem of the historical separation of 'sexuality' from sensuality, an emblem of the invention of sexuality as a newly constructed (and constricted) domain of experience, one that can no longer be confused with the broader domain of aesthetic perception"(81-82). Looby's insights into the "The Counterpane" chapter are valuable, but, as I have discussed elsewhere, I believe that his emphasis on sensuality over sexuality distorts Melville's literary exploration of the latter. ${ }^{7}$ The Nelson monument episode in Redburn, which more explicitly foregrounds the aesthetic mode, eschews the sensual in favor of the sexual. It explores the ways in which the sexually charged nature of aesthetic representation conveys awareness of non-normative sexual practices: a dread of their existence, an awareness of their potential threat, and also a languorous fascination, the erotic charge of which is inextricable from the dread. Aesthetic contemplation and ekphrastic response emerge as modes through which to register and negotiate-but also disavow, as Winckelmann's simultaneously homoerotic and ascetically distancing aesthetic philosophy advocated—disturbing and problematic desires that include same-sex desire.

\section{Mourning, Fathers, Race, and Sodomy: the Nelson Monument}

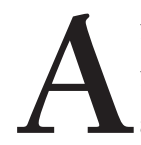

ntebellum authors infused their gendered depictions with a sense of mourning directly related to gendered identity, and antebellum literature is awash in the lost sons of patriarchy. Chapter 31 of Redburn, "With His Prosy Old Guide-Book, He Takes a Prosy Stroll through the Town," is a pre-psychoanalytic evocation and critique of the Oedipus complex that concludes with a critical staging of the Lacanian mirror stage, in which Redburn refuses identification with suffering white male bodies by re-inscribing these bodies as dark, not himself, and therefore, however pitiable, other. This version of the mirror stage simultaneously evinces awareness of the horrors of racism and disavows a homoerotic complicity that is also thematized in Melville's own writing in the chapter. ${ }^{8}$ 
While the narrator's now-famous evocation of his father's guidebook The Picture of Liverpool, riddled with markings made by Redburn's child-self, is a loving one, his connection to his dead father while in the city he once also traveled leaves the son profoundly disconnected. "Poor, poor Wellingborough!" Redburn thinks to himself, "miserable boy! you are indeed friendless and forlorn. Here you wander a stranger in a strange town, and the very thought of your father's having been here before you, but carries with it the reflection that, he then knew you not, nor cared for you one whit" (NN Redburn 154). Interestingly, the father who provides a guide becomes a figure Redburn seeks to find. He takes out his map, and traces his father's trajectory: "So vivid was now the impression of his having been here, and so narrow the passage from which he had emerged, that I felt like ... overtaking him round the Town Hall adjoining" (155). This striking sense of oedipal disconnection prepares us for Redburn's encounter with the Nelson monument.

Instead of finding his father in material form, Redburn finds a spectacular symbolic version of paternal power in sculptural form:

The ornament in question is a group of statuary in bronze, elevated upon a marble pedestal and basement, representing Lord Nelson expiring in the arms of Victory. One foot rests on a rolling foe, and the other on a cannon. Victory is dropping a wreath on the dying admiral's brow; while Death, under the similitude of a hideous skeleton, is insinuating his bony hand under the hero's robe, and groping after his heart. . . I I never could look at Death without a shudder. (NN Redburn 155)

As mentioned earlier, of chief interest to Sterling Stuckey are the four naked, chained figures at the base of the pedestal, which Redburn describes as "seated in various attitudes of humiliation and despair" (155). Stuckey calls our attention to the significance of Redburn's encounter with the monument and to Melville's evocation of anti-slavery. These "woe-begone figures of captives" are "emblematic of Nelson's principal victories," but their "swarthy limbs and manacles," Redburn tells us, "involuntarily" remind him of "four African slaves in the market-place" (155). Redburn then meditates on the inhuman treatment of slaves and abolitionist controversies. Deeply affected by the statuary, he stares at it each time he goes through Chapel-street, always "sure to find Lord Nelson still falling back; Victory's wreath still hovering over his swordpoint; and Death grim and grasping as ever; while the four bronze captives still lamented their captivity" (156).

This set-piece certainly deepens our understanding of Melville's critical disposition towards the slave trade. Without in any way diminishing the gravity of these matters, I want to call our attention to another detail as well: the perverse homoeroticism of the statuary spectacle, perhaps inherent to the monument but 
especially vivid as Redburn describes it. This ekphrasis not only heightens the hideousness of slavery but also seizes upon an opportunity to represent malemale intimacy. Melville uses the gothic mode to register the mingling of horror and pleasure in same-sex intimacy of a particular kind: the sodomitical shipboard practices that he found simultaneously titillating and horrifying.

As Caleb Crain observes, before the emergence of modern sexual taxonomies, cannibalism functioned on several metaphorical levels, one of which was homoerotic desire. Citing Théodore Géricault's 1819 painting Le Radeau de la Méduse (The Raft of the Medusa) as an example, Crain, pointing to the homoerotic potentiality inherent in the desire to eat another man's flesh, argues that such scenes of deprivation and depravity gave the painter license to place male bodies in erotically intertwined positions, a male-male intimacy that would be otherwise unrepresentable. As the recurring themes of Poe's Narrative of Arthur Gordon Pym demonstrate, cannibalism provides an opportunity to register both homoerotic desire and horror, hence its usefulness to an author who has an eye on the literary marketplace as well as his own conflicted responses. Following James Creech, I argue that Melville uses the gothic mode, here and elsewhere, to express similarly conflictual responses.

While the chained male figures at the base of the monument evoke slavery, they also are represented as suffering young white males who are partially nude. Nelson is similarly represented as an almost nude figure, albeit a heroic one. Given that so much of Redburn's attention is focused on the suffering of young white males at the hands of older white males, it is significant that beneath a figure of triumphant though expiring military might-the cynosure of nautical and national power-cower figures whose attitudes of despair signal the suffering of young men who must serve under more powerful men. Moreover, despite their abject postures-some covering their faces with their hands, others with their heads in their hands, all with their heads downcast, evocative of physical and spiritual mortification at once-the conventionally classical body typing in these figures emphasizes their muscled, masculine physical form. Adding to the homoeroticism of the sculpture, around the base itself are panels in bas-relief of scenes from military conquests, full of male figures with similarly classical musculature in groupings that alternately depict Nelson's sailors doing battle with opposing forces or capturing them as prisoners of war, prostrate on the ground and being pulled.

That Melville saw something alive and volatile-in a word, strange-in this monument was not a surprise. The monument frequently provoked controversy. John Griscom, a New York City chemistry professor, education leader, school-builder, reformer, and philanthropist whose biography in the Cyclopaedia of American Literature recalls the enterprising variousness of Benjamin 
Franklin's endeavors, described the monument as "barbarous" in his 1824 collection of travel writings A Year in Europe (61). The reasons he gives for his assessment are suggestive:

Nelson is leaning back in an uneasy posture, with one foot trampling on the carcass of a dead man. Death is seen with his marrow bones peeping from behind a shroud, and, reaching out his arm, is grasping at Nelson's heart! Beneath are four figures, representing different powers of Europe, sitting round the monument in a forlorn posture, with their hands chained to the stone near the feet of their conqueror (27).

Though Griscom praised the exquisite skill of the monument's design, he confesses that "it appeared to me to breathe a spirit, which would better befit the capital of a nation of which a Cortes or a Tecumseh was the ruling chief. The triumph of a Christian nation ought surely to be differently exhibited" (27).

Others shared Griscom's apprehensions. The Reverend Noah Worcester, one of the founders of the pacifist Massachusetts Peace Society, established in 1815, wrote in response to Griscom in The Friend of Peace, a quarterly journal of the Society that Worcester edited and for which he served as principal contributor from 1819 to 1828 :

Who would have supposed that a people so enlightened as the Britons, in the
nineteenth-century, would have thought it an honor to themselves or their
hero, to represent him in the disgusting and barbarous attitude of "trampling
on the carcass of a dead man?" ... was it to have been expected that a Chris-
tian people would associate with this honor an insult to other nations by fig-
ures representing four of them ... Was this necessary? Was it Christian? Was
it magnanimous? Was it humane? . . . What must be the feelings of people
from those various countries on beholding the Monument? (74-5)

That commentators of the early nineteenth-century-Griscom was a pioneer of the transatlantic movement that would be known as the Grand Tour of Europeapprehended the weirdness of the Nelson monument, with its odd figures of the white slave (technically not what the manacled prisoner of war figures were, but the idea they were rumored to evoke) and "marrow bones" monster-Death. Their responses prepare us to understand that Melville, with his keen interpretive insight, saw this weirdness as well. He may have appreciated the ambivalence in a commemorative work that seemed to be undermining the military "Victory" it celebrated, presided over by an allegorical female form, witness or overseer to a strange male pageant of suffering, desire, beauty, and death.

In the monument, the homoeroticized naked male body of Nelson is invaded by the figure of Death. As Redburn describes it, "Death, under the similitude of a hideous skeleton, is insinuating his bony hand under the hero's 


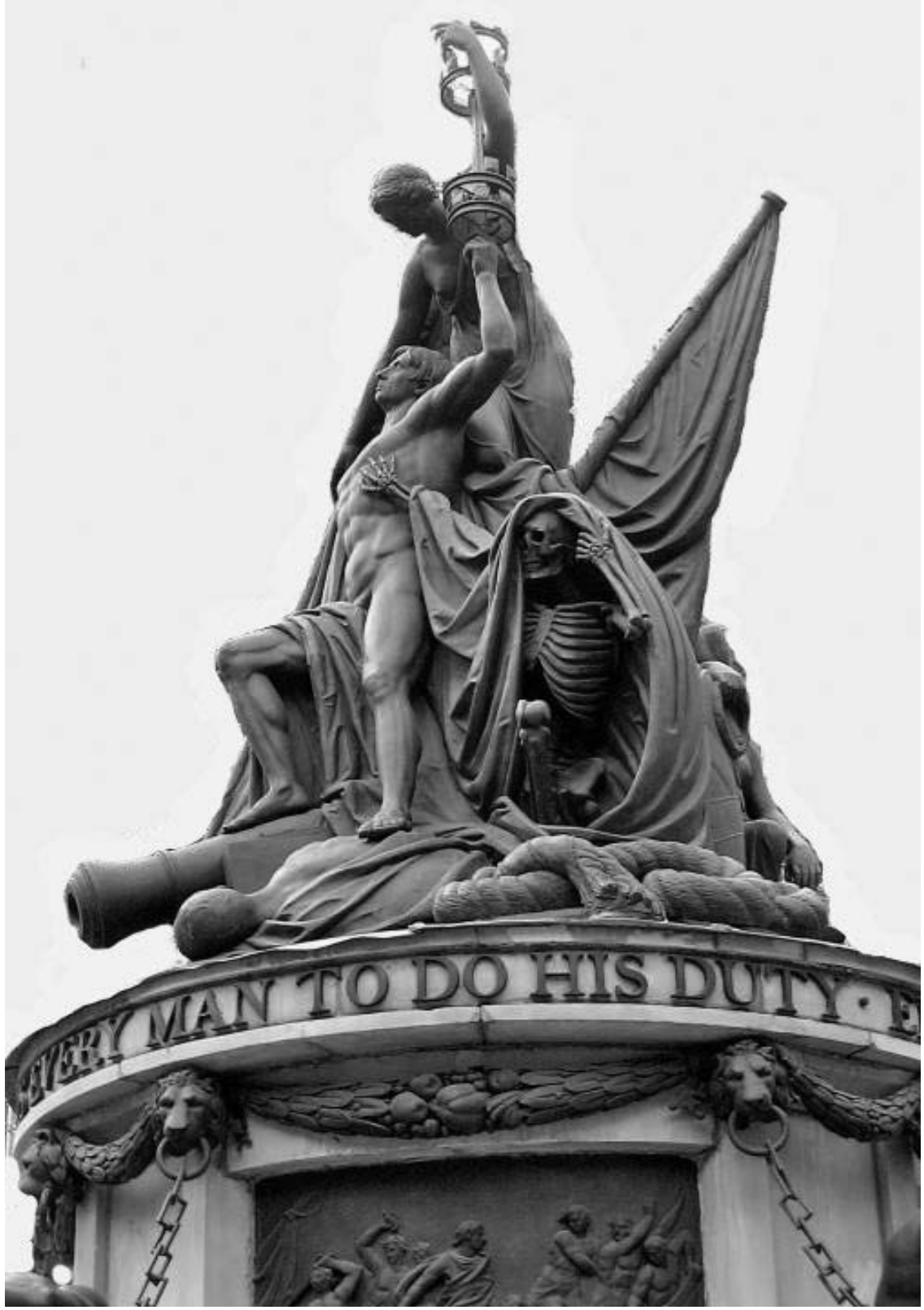

Fig. 3. Allegorical figure of Death in the Nelson monument. Redburn describes the figure: "Death, under the similitude of a hideous skeleton, is insinuating his bony hand under the hero's robe, and groping after his heart" (NN Redburn 155). Photograph by Robert Freidus, courtesy of Victorian Web. 
robe, and groping after his heart" (NN Redburn 155; see Fig. 3). If considered as an allegorical commentary on the action of the novel, Melville's ekphrastic depiction here emphasizes both violation and its homoerotic qualities. "Insinuating" and "groping," Death's bony hand invades sacrosanct white male flesh with the impropriety of the unwelcome advance. John Griscom's consternation at the monument may have been influenced by his awareness of the odd sexual subtexts in the representation of Death's invasion of Nelson's heroic, nearly nude form. Griscom's alarm has an almost erotic register: "Death is seen with his marrow bones peeping from behind a shroud, and, reaching out his arm, is grasping at Nelson's heart!"

Another contextualizing intertext is the public discussion of sodomy and the sodomite that preceded Melville's writing of Redburn. Mary Lefkowitz Horowitz has brought to our attention "the racy weeklies written for sporting men or those who aspired to join their company" that emerged on the print and cultural scene in New York City in the early 1840s. The "flash" press "focused on popular entertainments and commercial establishments but gave special attention to brothel life" (24-5). In the January 29, 1842, sporting weekly Whip, this incensed account of a new threat appeared:

THE SODOMITES.-We hope that in presenting to our readers a sketch of some of the inhuman enormities that a set of fiends bearing the form of men are nightly in the habit of disgusting nature with their monstrous and wicked acts; our excuse must be, that we have undertaken to rout from our city these monsters.

We know them all by sight, and most of them by name. They are nearly all young men of rather genteel address, and of feminine appearance and manners; among this herd of beasts is one or two old and lecherous villains whom we know well. (Horowitz 2006, 137-8) ${ }^{9}$

The Whip writer laments the plight of a "youth of our acquaintance, who was so unfortunate as to fall within the snare of this old sodomite and his beastly crew," and describes the "decline which so emaciated his form ..." The writer then asks, "To what has New York" come? There is "no difference between the doings of these fiendish agents of the Palais Royale and the brutal sodomites of New York" (Horowitz 2006, 137-8). As Horowitz notes, the commercial arcades of the Palais-Royal became known as a place for males to pick other males up for sex.

After being unsuccessful at finding work, Melville sailed in January 1841 on a voyage to the South Seas on the whaler Acushnet, which, in June 1842, would anchor in the Marquesas Islands, where the young author had experiences that he would immortalize in the 1846 Typee. Melville was not in New York City, then, when this issue of Whig came out. But knowledge of 
the sodomite community and its threat were part of the anxiety over urban life long before the article appeared. Timothy Gilfoyle has established that a "nascent male homosexual subculture" was already developing in New York City by the 1840s, and, as Leland S. Person notes, "Melville must have known as much about this subculture as Walt Whitman; for a discourse of male prostitution invades many male-to-male solicitations in The Confidence-Man. And the Melville who played so many sexual jokes on his readers-isn't he cruising the reader ... rubbing our noses, as it were, in the face of pederastic desire?" (Gilfoyle 135; Person 242).

The Navy drummer Philip C. Van Buskirk makes it clear in his diary entry of Wednesday, October 19, 1853, that he understands exactly what "sodomy" means:

PAEDERASTY—SODOMY. To prevent confusion of meaning . . . I first met with "paederasty" in Gibbon's Rome. . . . I understand the word to mean the practice of sodomy between two males where the hand of each is used to pollute the other. ... On board of ships, paederasty (called "shaking") is not looked upon as a form of sodomy, but considered innocent and undeserving of reproach. I extend the signification of Sodomy to embrace every horrid unnatural use of the organs of generation: and as such, embracing Paederasty, where one must act for another, Onanism, where one acts for himself, and lastly the laying down of a male to act as a woman to another male, which form alone sailors call "sodomy." (Peiss 119; capital letters and emphases in the original text)

As has been discussed in Melville studies, the author, from his own experiences at sea, likely was familiar with the activities that Buskirk described. Melville also shared in the alarm over these activities. In the novel White-Jacket (1850), he exhibits an awareness of shipboard same-gender sex but also critiques the oppressive culture of sodomitical rape. Shipboard rape, as Caleb Crain points out, was an act in which powerless males were subordinated and humiliated by those men with authority over them. Redburn evinces a similar awareness and critique. In his description of the Nelson monument, Melville evokes the manner in which the predatory older sodomite might insinuate himself into a younger man's company and make physical advances.

\section{Swarthiness and Hellenism}

I $\mathrm{n}$ many ways, the proto-abolitionist rhetoric of Redburn's apprehension of the Nelson monument is the surface discourse allowed to Melville. His ability to read themes of racism and the plight of enslaved Africans of his own time into the meanings suggested by an 1813 monument reveals the narrator's 
ability to read allegory allegorically, since the monument is itself an allegory of British military victory and as such runs counter to Melville's reading. Nothing literally present in the monument represents members of non-white races or enslaved and suffering Africans. As the earlier commentary by Griscom demonstrates, this was a monument that inspired contrary readings, provoking feelings in the viewer that differed from its ostensible aim. In another example of the ambivalent reactions the monument elicited, the German travel writer Johann Georg Kohl wrote in 1844 that "This monument alone was enough to convince me, how much more difficult it is to erect a classical, tasteful group of this kind, than to criticize it when erected." Kohl's anxiety that somehow this classically styled monument had violated the codes of "taste" echoes the earlier discomfort registered by Griscom about a certain impropriety in the monument (49). Again, my view is that a certain sexual unseemliness, which Melville perceives, made the monument problematic to spectators.

If, as Crain argues, cannibalism could serve as a fervid allegorical means of registering homoerotic desire without explicit signification, it has also been argued that anti-slavery discourse focusing on the suffering bodies of slaves, usually male, could function in a similarly coded homoerotic register. In an essay that treats the early republic's construction of "the black body erotic," John Saillant discusses the lavish eroticization of the black male body, which emerged as a sign of Christian and sentimental discourses' mutual efforts to create an image of Christian love, intimacy, and republican brotherhood figured through benevolent interracial relations. With too much decisiveness in this otherwise astutely observed essay, Saillant notes, "Erotic representations of black men by white men are not records of sexual activity, but rather records of beliefs and feelings" (103). Whether they represented, on occasion, first-hand evidence of sexual relations, such representations must also have served to some extent—much as the suffering, wounded body of Jesus has also done-as a conduit for the expression of same-gender eroticism and sexuality.

Melville's Redburn describes these enchained male bodies as "swarthy." Redburn's associations of these swarthy white male bodies with black male bodies involves a preoccupation with their physicality as well as their metaphorical "blackness." The sexual implications within Redburn's thoughts of an intense, "swarthy" physicality get submerged within a more recognizable discourse of abolitionist sympathy, in contrast to the coded language of homoerotic desire that suffuses Redburn's apprehension of the monument. In my view, or perhaps, to my ear, these implications echo throughout the ekphrastic meditation on the monument.

The swarthiness that Redburn apprehends in these white, classically styled sculptural bodies evokes an entire set of controversies over Hellenism 
that, in the wake of Martin Bernal's Black Athena and the numerous and often heated debates it has inspired, has come to be seen by some critics as a racist practice that, in ennobling the "Greek ideal," also ennobled an idealized white racial purity. ${ }^{10}$ One aspect of Hellenism unsettles, though does not resolve, the argument that it was a racist discourse: its relevance to an emergent nineteenth-century queer aesthetic. The transatlantic homoerotic investments in Hellenism in the nineteenth-century have been well-documented in works by Alex Potts, Linda Dowling, Michael Moon, and others. I argue that Melville's Redburn provides early evidence of the interest in the homoerotic dimensions of classical art, here evoked in the neoclassical style of the Nelson monument, that Melville would exhibit with greater frequency in the later stages of his career. ${ }^{11}$ Just as allegorical registers such as cannibalism allowed for the expression of culturally silenced homoerotic desires, so, too, did Hellenism allow for the coded expression of these otherwise inexpressible desires.

Teresa Goddu has discussed the significance of the figure of the classical "white slave" for the gothic mode and for antebellum racism and racial anxiety. The American neoclassical sculptor Hiram Powers's The Greek Slave, a decorous image of white, enslaved femininity that crossed the Greek ideal with Christian feminine humility, was produced in several versions between 1844 and 1869 and "was seen by over one hundred thousand people in America during the late 1840s and 1850s.... Surrounded by her veil of purity, the statue turns her spectators' potentially sexual inquisitive glances into reverential admiration" (Goddu 98-99). More recently, Nell Irvin Painter, in her study The History of White People, has reopened the question of nineteenth-century Hellenism and race by considering the racial implications of Winckelmann's theories. Winckelmann was one of the great innovators not only of the nineteenth-century classical craze but also the homoerotic Hellenism of the Victorian era. Painter points out that Winckelmann, unaware that the sculptures of classical Greece were painted and relying on the Roman copies of them, reverenced a white standard that he claimed the colorless, "white" statues of ancient Greece embodied. Painter alerts us once again to the racism underlying Winckelmann's homoerotic Hellenic aesthetic: he reverenced these "beautiful young men carved of hard Italian marble that shone a gleaming white" (61).

In effect, Melville restores the vivid color of classical statuary in Redburn's apprehension of the "swarthiness" of the classically styled bodies in the Nelson monument, at least insofar as he sees a color in their whiteness. Paradoxically, this apprehension of color seems to erase the question of sexuality. Sexual issues do, however, find a vent, not only in the suffering bodies of the enchained male figures but also in the shocking vulnerability of the otherwise triumphant male figure of Nelson, crowned by Victory yet besieged by Death. 


\section{Claws and Shudders}

few years after Redburn, Philip Buskirk would write in his diary about
the "paederastic" activity of male-male masturbation that he refers to
by the colloquial term "shaking." In his analysis of Buskirk's diaries, Barry Richard Burg notes that Buskirk mistakenly got the impression from Gibbons' Decline and Fall of the Roman Empire that pederasty referred to mutual masturbation, noting that "illiterate sailors rarely used classical terminology to identify sex acts," having learned nomenclature from each other. "Mutual masturbation to them was going "chaw to chaw" (77). Drawing on but also adding to Buskirk and Burg, Hershel Parker elaborates, in the context of White-Jacket, on Melville's version of these practices, desires, threats, tensions:

On shipboard were "even worse horrors" than were to be found in Horace Walpole's Mysterious Mother, Sophocles' Oedipus Tyrannus, and the story dramatized by Shelley in The Cenci. It was forcible rape that evoked such portentous citations, but rape, from the evidence of Van Buskirk, was extremely rare, while mutual assistance of casual "chaw for chaw" (or "claw for claw") was very common in snug places aboard ship. Denouncing in one place, teasing in another, Melville was employing again the characteristic elusiveness that had so enraged G. W. Peck in 1847. (657)

Parker refers here to George Washington Peck's essay in the July 1847 American Whig Review in which Peck, among others, found Melville's writing in Typee redolent, in Parker's words, of a "special prurience." Peck and Horace Greeley "charged Melville not merely with sexual license but with a strange sexual perversity that was not recognizable at first reading but that wormed its way into the reader's consciousness insidiously, as time passed" (Parker 530). The Nelson monument is an apposite complement, then, to Melville's work, provoking quite distinct responses from its apparent intentions. Even though he employed coded, allusive, playful techniques that are now perceived as characteristic of his work, Melville, as Parker usefully explains, still garnered negative attention as a sexually perverse author who maddeningly got under one's skin, a "sexually dangerous, and even depraved author . . . whose experiences fueled diverse sexual fantasies of many men and some women" (529-30). As Parker argues, these textual dynamics and reader responses to Melville's early works helped to make him "the first American author to become a sex symbol" (530).

"Death, under the similitude of a hideous skeleton, is insinuating his bony hand under the hero's robe, and groping after his heart" (NN Redburn 155). It is difficult to read this description in light of the commentaries of Burg and Parker without finding in it the echo of chaw-to-chaw or, more to the 
point, claw-to-claw, male-male sex. Melville suggests that even the pristine, noble, erect male body of the glorious national hero Nelson falls prey eventually to the claw of Death, a gesture that suggests the Old Reprobate of Buskirk's horror-titillation. Melville may be said to be figuring Death as an old sodomite/ pederast or figuring such a personage as Death.

"I never could look at Death without a shudder." Just as "shaking" hands with other men in Buskirk's sense signifies male-male masturbation, so too, in my reading of antebellum texts, does the term "shudder" signify, at times, homoerotic desire and its attendant phobic recoil. William H. Gilman observes that "Redburn shudders transfixed as he views the ocean of malice glistening in Jackson's snakelike eye, he fears him and suffers from his hatred, but the conflict between the two engenders no complex crisis" (218). (Jackson is the misanthropic seaman on board the Highlander who bullies Redburn; the protagonist eventually develops some sympathy for the older, venomous man.) I disagree with Gilman's claim that Melville's art had not yet achieved maturity in Redburn. But I am struck by Gilman's description, particularly of Redburn shuddering transfixed. This phrase is a resonant way of describing not only Redburn's relations with other men generally but also a key thematic in antebellum depictions of such relations. For Melville and for authors such as Poe and Hawthorne, the drama lay in the moments in which one man shudders in the presence of another.

In Poe's Narrative of Arthur Gordon Pym, Pym's descriptions of Dirk Peters can be understood as allegorical representations of both male sexuality and genitalia. The phallic aspects of Dirk Peters inform moments such as the one in which Pym initially encounters Peters and offers a lengthy description of him. As Pym notes, "To pass this man with a casual glance, one might imagine him to be convulsed with laughter-but a second look would induce a shuddering acknowledgement, that if such an expression were indicative of merriment, the merriment must be that of a demon" (87; emphasis added). In 1852, at the time Buskirk was writing his diary, Miles Coverdale in Nathaniel Hawthorne's novel The Blithedale Romance narrates his experiences of erotic desire for his fellow male as well as female utopians. Of the prison reformer Hollingsworth, Coverdale observes, comparing his impressions to those of women, that if "[Priscilla] thought him beautiful, it was no wonder. I often thought him so, with the expression of tender, human care, and gentlest sympathy, which she alone seemed to have power to call out upon his features. Zenobia, I suspect, would have given her eyes, bright as they were, for such a look" (Hawthorne, Blithedale 72). Coverdale's appreciation for Hollingsworth's beauty is intense enough to cause him alarm: "In my recollection of his dark and impressive countenance, the features grew more sternly prominent than the reality. ... On meeting him again, I was 
often filled with remorse. ... But ... in my silent chamber, the dark face frowned at me again." These thoughts lead Coverdale to declare that, besieged by images of Hollingsworth, he "shuddered in solitude" (71).

In the writings of Poe, Melville, and Hawthorne, "to shudder" emerges as a verb that expresses one's responses to beholding another man and having a powerful reaction to him. This ocular apprehension occurs within scenes of male physical display in which one man gazes upon another; a quality of fearfulness inheres in all of these dynamics; but appreciation for the wonder of another man's appearance informs the fear: these aspects add up to a portrait of male-male desire and its attendant panic, or, more precisely, a register in which both desire and the panic it triggered could be expressed.

The theme of violation becomes increasingly prominent in Melville's work, centering on the image of a vulnerable younger male being violated by an older and more powerful one. Such an image informs works such as Redburn, White-Jacket, Moby-Dick, The Confidence-Man, and Billy Budd, Sailor. The suffering experienced by Redburn's beloved Harry Bolton, a dandyish and charming young man vilely abused by a host of "ocean barbarians," conveys Melville's attitudes towards the potential victimization of all young males: "How they hunted you, Harry, my zebra!" Redburn laments, "those ocean barbarians, those unimpressible, uncivilized sailors of ours. How they pursued you from bowsprit to mainmast, and started you out of your every retreat!" (NN Redburn 253). Melville is horrified by the abuses young men suffer. But there is also an element of sadistic pleasure here beneath the more explicit anguish and horror, a sense of play that will also animate the horrific yet erotic atmosphere of "Benito Cereno."

Redburn's weird association of dandyish, victimized Harry Bolton with a hunted "zebra" is suggestive. Redburn would appear to be making an association between persecuted Harry and the fauna of Africa. If, as Leland S. Person argues, Harry becomes a "willing sex slave," naming him a zebra has disquieting racial, perhaps even racist, connotations. Melville once again collapses discourses of race and sodomy, since Harry would appear to have been forced into a male version of white slavery, or prostitution.

\section{Babo's First Blood}

W hile a great deal more about Redburn and antebellum homoeroticism remains to be said, it is with a sense of perverse shuddering — fearful and painfully pleasurable- that we can turn, by way of a conclusion, to an important scene in Melville's short story "Benito Cereno" that takes the race-sex allegory of Redburn to a different and richer level. "Benito Cereno" 
was serialized anonymously in three installments of Putnam's Monthly Magazine in 1855; it was collected the following year, in slightly revised form, in Melville's The Piazza Tales. In "Benito Cereno," Melville fictionalized the real-life Massachusetts Captain Amasa Delano's account of his experience of a slave uprising on a Spanish ship in which the slaves controlled their former masters. Sterling Stuckey has argued for the connections between "Benito Cereno," and Redburn, discussing their importance to Melville's critique of slavery (African Culture and Melville's Art 37-40). The issue of homoerotic desire and its perceived threat needs to be part of such reconsiderations. Melville treats racism as a problem of relations between men, relations that have a homoerotic complexity.

In one key scene of "Benito Cereno," Babo, the cunning leader of the slave uprising, shaves the vulnerable, terrified, yet passive Don Benito as the clueless Massachusetts captain Amasa Delano looks on. Babo secretly controls Don Benito and forces him to perform, for Delano's benefit, the masquerade that Don Benito is still captaining the ship that Babo has overtaken. The shaving scene represents the height of this masquerade: Don Benito's powerlessness, Babo's sadism, and Delano's myopia. It is also one of the most homoerotic scenes in antebellum American literature.

Setting down his basin, the negro searched among the razors, as for the sharpest, and having found it, gave it an additional edge by expertly strapping it on the firm, smooth, oily skin of his open palm; he then made a gesture as if to begin, but midway stood suspended for an instant, one hand elevating the razor, the other professionally dabbling among the bubbling suds on the Spaniard's lank neck. Not unaffected by the close sight of the gleaming steel, Don Benito nervously shuddered; his usual ghastliness was heightened by the lather, which lather, again, was intensified in its hue by the contrasting sootiness of the negro's body. . . ."Now, master," [Babo] said . . ."now, master," and the steel glanced nigh the throat.

Again Don Benito faintly shuddered. (NN PT 85; emphasis added)

As with the interracial "honeymoon" shared by Ishmael and the Polynesian savage Queequeg in Moby-Dick, race relations here become highly sexually charged, as if the difference in men's races is emphatically registered in the sexual frisson produced by their bodily contact. That Delano must witness this act of menace, that the menace is so homoerotically charged, that Babo orchestrates the entire encounter as a performance for an audience and for the further subjugation of Don Benito, and that Don Benito is aware of his own subjugated position while also having to play along with Babo's sadistic game: all of these aspects give the scene its strange, theatrical perversity.

Redburn remarked that he could never see Death without a shudder; now, the cunning Babo assumes the role of Death, wielding a phallic blade 
above the effeminated, prostrate captive Spanish captain Don Benito's "lank" neck, making him shudder in anticipation of death, orgasm, or both. And when Babo chastises Benito Cereno for having made Babo draw his "first blood," the moment has an unmistakably sexual import. Blood, like the tears that course through Pym, provides another substitute fluid for male sexual release. The erotic intensity of Redburn's racial metaphors achieves a mesmerizing, menacing new clarity in "Benito Cereno." Both of these shuddering works make their arduous way through the horrors of racism and relations among men in a racist, masculinist world, locating the shifting place of homoerotic desire within the mingled terrors of race and queerness.

\section{Notes}

${ }^{1}$ Melville's interest in the sexual attractiveness of black males has a powerful homoerotic dimension that has been either overlooked or misinterpreted in recent criticism and comes through most forcefully in Billy Budd. The opening scenes, introducing the trope of the Handsome Sailor, offer a mesmerized blazon of the black male body. Gregory Jay attends to the allegories of race and black manhood in Billy Budd, but does not link these themes to the racialized homoeroticism present in the work.

${ }^{2}$ For Martin, the Harry character embodies Melville's ideal of a non-effeminate androgynous masculinity and the suggestive haziness of the "Aladdin's Palace" scene reflects the homoerotic intensity of the episode (Hero, Captain, and Stranger 49-50, 51). Martin's view has become standard. With a notable lack of fuss or contextualization, Hester Blum simply notes that "Aladdin's Palace" is a "homosexual brothel" (158).

${ }^{3}$ See Creech 93-155, who also discusses the gaze in the novel, especially the effect of Jackson's "stare" on Redburn (102-3).

${ }^{4}$ Caleb Crain discusses shipboard sodomy in Melville's novel White-Jacket: "The act of [same-sex] sodomy implied coercion and submission" in the nineteenth-century; "it was undemocratic." He argues that what bothers Melville about shipboard life is that "there is no redress for male rape. .. . The victim of male rape is somehow disqualified as a citizen; he is not acceptable as a plaintiff, and therefore justice is impossible. . . Like female victims of rape, these plaintiffs are blamed for the crime." See Crain 25-53.

${ }^{5}$ These sections of Philip Clayton Van Buskirk's journals are excerpted in Peiss 117-119, The emphases and capital letters are in Buskirk's original text. The fullest scholarly discussion of the journals of Buskirk, who entered the Marine Corps in 1846 and was discharged in 1869, can be found in Burg, Erotic Diaries. See also Burg's Rebel at Large, which similarly notes Buskirk's fascination with handsome young males. For the continuing history of same-sex desire in a nautical setting, see Peter Boag, Same-Sex Affairs.

${ }^{6}$ The English translation of Winckelmann's 1764 The History of Ancient Art by G. Henry Lodge was the one that Hawthorne and Melville read before their trips to Europe in the 1850s. Both writers frequently echo Winckelmann's focus on the classical beautiful male body, such as the famous Apollo Belvedere. Published in 1849, Lodge's translation of the second volume, Art Among the Greeks, was the first to be published in the United States, probably because of this volume's Greek focus. The first volume, which focuses on Egyptians and Etruscans, was published in 1856. See Chapter 7, "Visual Identity," in Greven, Fragility of Manhood, for a discussion of Hawthorne and Melville and Winckelmann's homoerotic aesthetics.

${ }^{7}$ I outline the terms of my disagreement with Looby's reading of Melville, which has larger implications for the issue of same-sex desire in the antebellum period, in Gender Protest 31-4.

${ }^{8}$ When the child stares at its image in the mirror, it mistakes the illusory image of wholeness for an authentic wholeness. This méconnaissance is the basis from which a self is formed. The mirror stage is the key component of the Imaginary order, in which the ego is formed through a narcissistic fascination with one's own fragile, evanescent image. See Jacques Lacan, "The Mirror 
Stage." The scene of Redburn looking at the Nelson monument seems to prefigure Lacan's theory of the mirror stage, with an emphasis on anti-identification and disavowal.

9 "Sodomites," Whip 1.6 (Jan. 29, 1842); rpt. in Horowitz 137-8. Capital letters and emphasis in original reprinted text.

${ }^{10}$ For a collection of often quite critical counter-responses to Bernal's Black Athena, see Lefkowitz and MacLean. .

${ }^{11}$ Redburn complicates Robert K. Wallace's argument about the psychologically stabilizing effects of Melville's travels in 1856-1857, during which he encountered ancient, Renaissance, and nineteenth-century art ("Unlike Things Must Meet and Mate" 352). In Redburn, published in 1849, Melville reflects on his 1839 experiences abroad and his first exposure to the Nelson monument in Liverpool. We need to compare Melville's different travels at different times and the impact on his work at distinct stages of his career.

\section{Works Cited}

Bernal, Martin. Black Athena: The Afroasiatic Roots of Classical Civilization, Volume I: The Fabrication of Ancient Greece, 1785-1985. New Brunswick: Rutgers UP, 1987.

Boag, Peter. Same-Sex Affairs: Constructing and Controlling Homosexuality in the Pacific Northwest. Berkeley, CA: U of California P, 2003.

Blum, Hester. "Melville and the Novel of the Sea." The Cambridge History of the Novel. Ed. Leonard Cassuto. Cambridge; New York: Cambridge UP, 2011. 151-166.

Burg, Barry Richard, ed. An American Seafarer in the Age of Sail: The Erotic Diaries of Philip C. Van Buskirk, 1851-1870. New Haven: Yale UP, 1994.

- Rebel at Large: The Diary of Confederate Deserter Philip Van Buskirk. McFarland, 2009.

Casarino, Cesare. Modernity at Sea: Melville, Marx, Conrad in Crisis. Minneapolis: Minnesota UP, 2002.

Crain, Caleb. "Lovers of Human Flesh: Homosexuality and Cannibalism in Melville's Novels." American Literature 66.1 (1994): 25-53.

Creech, James. Closet Writing/Gay Reading: The Case of Melville's Pierre. Chicago: U of Chicago P, 1993.

Dowling, Linda. Hellenism and Homosexuality in Victorian Oxford. Ithaca: Cornell UP, 1994.

Duyckinck, Evert A. and George L. Duyckinck. Cyclopaedia of American Literature: Embracing Personal and Critical Notices of Authors, and Selections from Their Writings from the Earliest Period to the Present Day with Portraits, Autographs, and Other Illustrations. New York: C. Scribner, 1866.

Gilfoyle, Timothy. City of Eros: New York City, Prostitution, and the Commercialization of Sex, 17901920. New York: W. W. Norton \& Company, 1994.

Goddu, Teresa. Gothic America. New York: Columbia UP, 1997.

Greven, David. The Fragility of Manhood: Hawthorne, Freud, and the Politics of Gender. Columbus: Ohio State UP, 2012.

- Gender Protest and Same-Sex Desire in Antebellum American Literature. Burlington, VT: Ashgate Publishing Company, 2014.

Griscom, John. A Year in Europe. Vol. I. Collins \& Co., 1824.

Hawthorne, Nathaniel. The Blithedale Romance; and Fanshawe. Ed. Fredson Bowers et al. Columbus: Ohio State UP, 1971.

Horowitz, Helen Lefkowitz. Attitudes Toward Sex in Antebellum America: A Brief History with Documents. New York: Bedford/St. Martin's, 2006.

Jay, Gregory. "Douglass, Melville, and the Lynching of Billy Budd." Frederick Douglass and Herman Melville: Essays in Relation. Ed. Robert S, Levine and Samuel Otter. Chapel Hill: U of North Carolina P, 2008. 369-96.

Kohl, Johann Georg. Ireland, Scotland, and England. Vol. I. London: Chapman and Hall, 1844.

Lacan, Jacques. "The Mirror Stage as Formative of the Function of the I as revealed in Psychoanalytic experience." Écrits: A Selection. Trans. Bruce Fink. New York: W.W. Norton, 2002. 3-9.

Lefkowitz, Mary R. and Guy MacLean, eds. Black Athena Revisited. Chapel Hill: North Carolina UP, 1996.

Looby, Christopher. "Strange Sensations: Sex and Aesthetics in 'The Counterpane." Melville and Aesthetics. Ed. Geoffrey Sanborn and Samuel Otter. New York: Palgrave Macmillan, 2011. 65-84. 
Martin, Robert K. Hero, Captain, and Stranger: Male Friendship, Social Critique, and Literary Form in the Sea Novels of Herman Melville. Chapel Hill: U of North Carolina P, 1986.

Melville, Herman. The Piazza Tales and Other Prose Pieces, 1839-1860. Ed. Harrison Hayford, Alma A. Macdougall, and G. Thomas Tanselle. Chicago: Northwestern UP and the Newberry Library, 1987; cited as NN PT.

- Redburn: His First Voyage. Ed. Harrison Hayford, Hershel Parker, and G. Thomas Tanselle. Evanston and Chicago: Northwestern UP and the Newberry Library, 1969; cited as NN Redburn.

Moon, Michael. A Small Boy and Others: Imitation and Initiation in American Culture from Henry James to Andy Warhol. Durham: Duke UP, 1998.

Painter, Nell Irvin. The History of White People. New York: W. W. Norton \& Co., 2010.

Parker, Hershel. Herman Melville: A Biography. Volume 1: 1819-1851. Baltimore: The Johns Hopkins UP, 2005.

Peiss, Kathy, ed. Major Problems in the History of American Sexuality. Boston: Houghton Mifflin, 2002.

Person, Leland S. "Gender and Sexuality." A Companion to Herman Melville. Ed. Wyn Kelley. Malden, MA: Wiley-Blackwell, 2006. 231-47.

Poe, Edgar Allan. The Collected Writings of Edgar Allan Poe; Vol. I: The Imaginary Voyages (including The Narrative of Arthur Gordon Pym, The Unparalleled Adventure of one Hans Pfaall, and The Journal of Julius Rodman). Ed. Burton R. Pollin. Boston: Twayne Publishers, 1981.

Potts, Alex. Flesh and the Ideal: Winckelmann and the Origins of Art History. New Haven: Yale UP, 1994.

Saillant, John. "The Black Body Erotic and the Republican Body Politic, 1790-1820." Sentimental Men: Masculinity and the Politics of Affect in American Culture. Ed. Mary Chapman and Glenn Hendler. Berkeley: U of California P, 1999. 89-111.

"Sodomites." Whip 1.6 (Jan. 29, 1842).

Stuckey, Sterling. African Culture and Melville's Art: The Creative Process in Benito Cereno and MobyDick. New York: Oxford UP, 2008.

Wallace, Robert K. "Unlike Things Must Meet and Mate': Melville and the Visual Arts." A Companion to Herman Melville. Ed. Wyn Kelley. Malden, MA: Wiley-Blackwell, 2006. 342-63.

Winckelmann, Johann Joachim. The History of Ancient Art. Trans. G. Henry. Boston: J. R. Osgood, 1849.

Worcester, Noah and Massachusetts Peace Society. The Friend of Peace. Vol. IV. Joseph T. Buckingham, 1827. 